NASA Technical Memorandum 88877

\title{
High- and Low-Thrust Propulsion Systems for the Space Station
}

Robert E. Jones

Lewis Research Center

Cleveland, Ohio

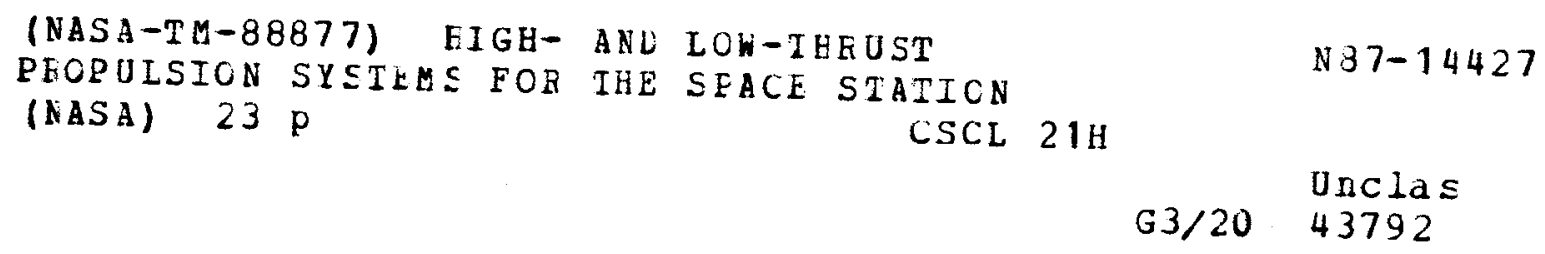

Prepared for the

25th Aerospace Sciences Meeting

sponsored by the American Institute of Aeronautics and Astronautics Reno, Nevada, January 12-15, 1987 
HIGH- AND LOW-THRUST PROPULSION SYSTEMS FOR THE SPACE STATION

Robert $E$. Jones

National Aeronautics and Space Administration

Lewic Research Center

Cleveland, Ohio 44135

\section{Abstract}

The purpose of the Advanced Development Program was to investigate propulsion options for the Space Station. Two options were investigated in detail: a high-thrust system consisting of 25 to $50 \mathrm{lbf}$ gaseous oxygen/hydrogen rockets, and a low-thrust system of 0.1 lbf multipropellant resistojets. An effort is also being conducted to determine the life capability of hydrazine-fueled thrusters. During the course of this program, studies clearly identified the benefits of utilizing waste water and other fluids as propellant sources. The results of the $\mathrm{H} / \mathrm{O}$ thruster test programs are presented and the plan to determine the life of hydrazine thrusters is discussed. The background required to establish a long-life resistojet is presented and the first design model is shown in detail.

\section{Introduction}

The purpose of this paper is to present the results of the Advanced Development Program that were specifically concerned with the propulsion systems for the Space Station. Through a process of evaluation a selection would be made, during the phase B Space Station effort, of the propulsion system to be employed on the IOC Space Station. This paper will briefly discuss the program content and the results that have been obtained.

Previous papers have discussed the content of the Advanced Development Program and its purposes in considerable detail.1,2 The planned thruster programs investigated both a high- and low-thrust propulsion system for the IOC Space Station. The choice of two propulsion systems with differing thrust and operational capabilities provides the Space Station propulsion options that have the capability for a wide variety of propulsion or thrusting capabilities. The propulsion systems selected for study were 25 to 50 lbf gaseous oxygen-hydrogen fueled rockets and the 0.1 lbf multipropellant resistojet. The combination of these two systems provides the Space Station with more possible ways of "flying" than are possible with a single thrust level system. The advantages of the dual-mode propulsion system are obvious ones. While sufficient force is available for all large motions of the Space Station, including contingencies for collision avoidance, delicate maneuvers are continuously possible at a thrust level that will not interfere with scientific research and observations.

One additional benefit of these choices for space Station propulsion is the synergism obtained by the integration of the propulsion system with other station systems. Sources of propellants are available from the life support system and from the scientific and materials laboratories. Utilization of these fluids alleviates two fundamental problems; resupply of propellants is minimized and the quantity of waste fluids that must be returned to Earth is lessened. The first results in a direct cost saving by reducing the mass to he carried into orbit. The second helps to solve a serious problem of storing and carrying down wastes and thus improves the Shuttles' payload capability in returning to Earth.

This paper will present information on the potential on-station propellant availability, and the results that have been obtained with the both high-thrust and low-propulsion system programs.

\section{Propulsion Requirements}

The Space Station propulsion system must be able to provide thrust for altitude maintenance, collision avoidance, attitude control, and momentum management. As the studies have cont inued during Phase $B$, the propulsion requirements have gradually risen. Initial requirements and choice of operating mode and altitude have all been rethought during this study phase. Initially, an altitude of $250 \mathrm{nmi}$ was assumed for the Station and altitude reboost would be conducted after each Shuttle docking. Presently the operating mode proposed for the Station is at a lower altitude and in a mode corresponding to an average acceleration of 0.3 micro-a. As the atmospheric density varies over an $11 \mathrm{yr}$ cycle, the altitude required will also vary.

Table 1 compares the total-impulse requirements for a growing and evolving Space Station over an $11-y r$ cycle for the initial $250 \mathrm{nmi}$ altitude with the present micro-g requirement. These values have been computed by assuming a 1995 IOC station of $5000001 \mathrm{~b}$ mass that arows to $1000000 \mathrm{lb}$ in $10 \mathrm{yr}$. Assumptions as to the frontal area and ballistic coefficient are also used to compute the impulse requirements. The values computed also assume a nominal atmosphere. Note that the altitude has been lowered by up to $70 \mathrm{nmi}$ which certainly eases the problems of the Shuttle getting to the Station. Most significant, however, is the six-fold increase in propulsion requirements. As missions in space go, the Space Station was never considered a mission where specific impulse of the propulsion system was paramount. However, as can be seen by the increased levels of total-impulse; propulsion system specific impulse is becoming more important and improved levels of specific impulse will be sought.

\section{Propellant Source}

To augment the thruster research efforts, several studies were conducted that investiqated the propellant source and resupply and their impact on thruster system design. 3-5 Initially, those studies assumed that the hydrogen and oxygen would be supplied from supercritical storage tanks simi1 ar to the PRSA (Propellant Reactant and Supply Assembly) tanks utilized on the Shuttle. As the studies progressed alternative sources of propellant appeared more attractive. It became apparent from studies of the Environmental Control and Life Life Support Systems (ECLSS) that the Station could have a significant water disposal problem. These 
studies clearly identified the potential of electrolyzing this water to provide the required oxygen and hydrogen and the concomitant savings possible by minimizing resupply. Additional sources of water were also found. Significant quantities of water are to be found on board the Shuttle and can be transferred to the Station. Such sources include water from fuel cells and waste water. The actual a vailability of water is still subject to decisions as to the choice of the environment control system Bosch or Sabatier - and the extent of water stored and withdrawn from the Shuttle. Table 2 shows the yearly levels of water available for each environmental system and assumes Shuttle visits at 45 or 90-day intervals and that Shuttle water is transferred to the station. The total levels of water a vailability are close to that required and can be substantially more depending on solar year, altitude and whether resistojets are also utilized. As indicated previously, the propulsion requirements for the Space Station have already increased, and may do so aqain. Assuming a specific impulse for the $0 / \mathrm{H}$ thrusters of $380 \mathrm{sec}$ at a mixture ratio of $8: 1,10000 \mathrm{lb}$ of water would be required to meet the total-impulse requirement for the year 1995 . As indicated in Table 2 sufficient water could be available to fulfill this propulsion requirement.

Water, however, is not the only potential propellant source. The selection of the multipropellant resistojet adds significantly to the overall propulsion capability of the Station. Continuing studies indicate that there are larqe quantities of waste gases that could be made available for propulsion. If these gases are not utilized for propulsion, then they must be stored and disposed of by a suitable means. That could mean that these excess or waste fluids would be returned to earth. Table 3 lists the levels of fluids available from the Bosch and Sabatier environmental systems.

Table 4 lists other fluids that are believed to be available from the Materials Technology Laboratory (MTL). Rather than vent or return these gases to Earth we propose to use them as propellants for the resistojet. The total availability of all fluids from all sources is given in Table 5, assuming that the Sabatier System is chosen for ECLSS. This leve? of propellant supply when coupled with that available from the electrolys is of water clearly goes a long way toward supplying the Station propulsion requirements.

\section{High Thrust Propulsion}

The high thrust propulsion system was selected to be gaseous oxygen-hydrogen fueled rockets. The presumed thrust level was chosen to lie within the 25 to $50 \mathrm{lbf}$ range. While no absolute thrust size could be predetermined, this size seemed the correct one to identify any technology issues. This program specified that the $0 / F$ mixture should be $4: 1$ for these rockets as this would provide maximum values of specific impulse. Later, the potential use of propellants from water required that tests be conducted at a mixture ratio of $8: 1$. The program goal was primarily life oriented. Performance (specific impulse) would be sacrificed to achieve long operation life. This effort to investigate life capability of small rockets is just beginning and will continue with more emphasis on $8: 1$ mixture ratios.

Three small rockets, provided by three different manufacturers were included in this program.
Aerojet Techsystems provided a 25-1b thruster and Bell Aerospace provided a 50-1bf thruster; both under contract to NASA Lewis. Rocketdyne provided a 25-1bf thruster, constructed as part of their IRAD program, to Marshall Space Flight Center where the performance and i ife tests were conducted. ${ }^{8}$ The results of these test efforts have been extensively reported elsewhere. ${ }^{6-9}$ Table 6 compares the basic design parameters of the Aerojet, Bell, and Rocketdyne thrusters. Fiqure 1 shows the Aerojet thruster mounted on a thrust stand. Fiqures? and 3 are photographs of the Bell and Rocketdyne thrusters respectively. These thrusters all operate at modestly low chamber pressure and have similar overall dimensions. They do, however, differ markedly in the design approach taken, method of fuel injection, nozzle area ratio, and extent of regenerative cooling employed.

When the decision was made to test these thrusters at a mixture ratio of $8: 1$, it was clear that some thruster design modification was in order. Time did not permit a redesign of each thruster, so compromises were made. For example, the Aerojet thruster with regenerative cooling of the 100:1 area ratio nozzle should have been redesigned to a smaller area ratio. As this was not possible, the effect was simulated by cooling the hydrogen to a level such that fuel injection temperature would be that value estimated for less regenerative cooling. In a similar manner the Bell thruster material was changed to Hastelloy $x$ from 347 stainless steel and the hydrogen cooling flow was held constant. This resulted in a higher thrust and chamber pressure at a mixture ratio of $8: 1$. The Rocketdyne thruster had the regenerative cooling flow rerouted, utilizing down-pass cooling instead of up-pass cooling. At no time were any operational difficulties encountered and the test program proceeded as planned. Table 7 lists the total number of seconds of testing for each thruster at mixture ratios from 2:1 to $8: 1$. Note that large times were obtained at mixture ratios of $7: 1$ and $8: 1$. Table 7 also shows the total impulse demonstrated by each thruster over the same range of mixture ratios. The life goal $2 \times 10^{5} 1 \mathrm{bf} / \mathrm{sec}$ was achieved by the Rocketdyne thruster. Time and funding limited the test programs with Aerojet and Bell but larqe values of total-impulse were obtained at high mixture ratios.

These results clearly illustrate that the program goal for life was obtainable. Indeed, an examination of the physical state of the thrusters leads one to conclude that the actual obtainable life is substantially greater. It is important that the life of such thrusters be determined for two reasons. First, just to know and have a reasonable expectation of what life might be planned for, and secondly, to determine the failure modes that lead to life limitation. Future tests are planned to address these issues, as well as to strive for increased levels of specific impulse. It is also important to recognize that these life results were obtained with three different design concepts, provided by three separate contractors.

Figure 4 compares the specific impulse performance obtained with the Aerojet and Bell thrusters over the mixture ratio range from $2: 1$ to $8: 1$. Both thrusters suffered significant decreases in specific impulse as mixture ratio increased. The data obtained with the Bell thruster were taken with a fixed configuration and a fixed hydrogen flow rate 
in order to assure adequate cooling of the throat. Thus chamber pressure and thrust level were increasing as mixture ratio increased from $4: 1$. The Aerojet data were obtained with varying splits of hydrogen used for film cooling; up to 92 percent being used for film cooling at a mixture ratio of $8: 1$. These losses in performance for both designs were greater than anticipated and reflect nonoptimized designs. Performance improvements $c$ an be obtained by redesigning these thrusters and recognizing that operation will be required over a wide range of mixture ratios, but with primary operation near a mixture ratio of $8: 1$. The impact of such design changes on total life of the thrusters will have to be determined.

Hydrazine Thruster Life Test

The requirement that any propulsion system for the Space Station exhibit long life has led to an investigation of the life capability of hydrazinefueled thrusters. Generally, the actual operating lifetime of such thrusters is poorly known. The life requirement of the Space Station makes the determination of component life and the evaluation of 1 ife improvement concepts of critical importance. At the Lewis Research Center we have undertaken an effort to determine the actual useable life of a small, 5-lbf, hydrazine thruster. The thruster is provided to the program by Rocket Research under the aegis of a cooperative agreement with NASA. The thruster will be instrumented and installed on a thrust stand in the Rocket Engine Test facility (R.E.T.F.). Figure 5 is a photograph of the thruster provided for test by Rocket Research. This thruster incorporates their latest technology to obtain long life from the catalyst bed. A spring mechanism surrounding the catalyst bed will continually apply compression to the catalyst bed to prevent the formation of and/or collapse any void channels. It is the presence of large voids or channels with in the catalyst bed that cause rough operation (chamber pressure fluctuations) leading to reduced operational life.

The Rocket Research thruster will be tested over an operational cycle of steady-state and pulse firing that simulates the Space Station duty cycle. The program will attempt to obtain 2 million $1 \mathrm{~b} / \mathrm{sec}$ of total impulse from the present thruster and performance and chamber pressure will be continually monitored. Figure 6 shows a small thruster mounted on the test stand in RETF. The thruster will exhaust into the diffuser shown at the left to assist in maintaining a low pressure within the test capsule. A low pressure is obtained primarily by the use of air ejectors which are capable of providing continous low pressure for these tests. Future tests are planned where the life capability of the Aerojet and Bell H/0 thrusters will be determined.

\section{Low Thrust Propulsion System}

The application of the resistojet as a Space Station propulsion system imposes new operational considerations on the design of such thrusters. Use of resistojets in a wide variety of spaceqraft applications is well known and documented.10,11 Resistojets for these applications may be characterized as having a requirement for maximum specific impuise, short operating lives, and use with a single propellant. As has been indicated previously, the primary criteria for a Space Station resistojet are long life and operation with a wide variety of potential propellants.2,3

Since the Space Station resistojet has different criteria from high performance resistojets, it is critical that the design chosen be based on a solid foundation. First and foremost, it was obvious that material-propellant compatibility had to be addressed in order to select a resistojet material that could be expected to provide the useful life required. The wide variety of possible propellants from ECLSS, MTL, attached, payloads or other sources all had to be studied. A resistojet material had to be selected that would have minimum interaction with such propellants. For our studies we examined two forms of grain stabilized platinum. Platinum had been a previous choice for a biowaste resistojet considered in the 1970's because of its excellent resistance to corrosion and oxidation. Resistance to grain growth, a time at high temperature phenomenon, was required to minimize the likelihood of stress-rupture. The program studied both yttria and zirconia grain stabilized platinum materials.

Figure 7 shows the test chamber used to evaluate the Platinum alloy heaters in contact with potential propellants. These tests were conducted with $\mathrm{H}_{2}, \mathrm{CH}_{4}, \mathrm{CO}_{2}, \mathrm{NH}_{3}, \mathrm{~N}_{2}$ and steam in a flowing gas environment at a pressure of about $1.4 \mathrm{~atm}$. All tests except those containing $\mathrm{CH}_{4}$, either alone or in mixtures, were conducted at a heater temperature of 1300 to $1400{ }^{\circ} \mathrm{C}$. Gases containing $\mathrm{CH}_{4}$ were tested at a temperature of $500{ }^{\circ} \mathrm{C}$ to avoid thermal decomposition of $\mathrm{CH}_{4}$. These tests were conducted for as long as $2000 \mathrm{hr}$ and have been reported in detail in Refs. 12 and 13 . Test results are summarized in Table 8 and indicate that from a material, or mass loss, standpoint, a $10000 \mathrm{hr}$ operational life should be easily obtained with all propellant-material combinations studied. Fiqure 8 shows a micrograph cross-section of the heater tube both before, and after a 2000-hr test at $1300{ }^{\circ} \mathrm{C}$ with $\mathrm{CO}_{2}$. No siqnificant grain growth has occurred and surface attack by $\mathrm{CO}_{2}$ has been minimal. Surface attack was significant with ammonia at $1400{ }^{\circ} \mathrm{C}$, and though no mass loss was observed, a life of $10000 \mathrm{hr}$ would probably not be obtained. When the heater temperature was reduced below $1000{ }^{\circ} \mathrm{C}$ surface attack virtually disappeared.

These tests have recently been expanded to include hydrazine as a potential resistojet propellant. Tests of up to $1000 \mathrm{hr}$ have been conducted with yttria-stabilized platinum at temperature of 1000 and $1400{ }^{\circ} \mathrm{C}$. Similar results to those obtained with ammonia have been obtained. 14 That is, surface attack at $1400{ }^{\circ} \mathrm{C}$, but no noticeable effect when the temperature was lowered to $1000^{\circ} \mathrm{C}$.

These tests served several valuable purposes. The compatibility of the platinum material was confirmed with many potential propellants, useful lifetime data were obtained and where materialpropellant attack occurred, a useful operational temperature range has been determined.

A further evaluation of the resistojet as a structure was obtained by conducting a 2000-hr life test using $\mathrm{CO}_{2}$ as the propellant. The purpose of this test was to determine the impact of cyclic thermal and mechanical stresses on the platinum 
material as well as the welded joints. At the conclusion of the tests the thruster shown in Fig. 9 was sectioned to examine the interior surfaces for attack. As expected, there was no effect of this test on the structure that could lead to a life limiting problem. These tests help to establish the basic design and operating parameters for the resistojet for Space Station application. Table 9 lists these parameters for a variety of possible propellants. The fundamentals of the design are; a maximum heater temperature of $1400{ }^{\circ} \mathrm{C}$, a power level of $500 \mathrm{~W}$, and a design operating life of $10000 \mathrm{hr}$. Also shown in the table are expected values of specific impulse and thrust with the various propellants. The laboratory model resistojet shown in Fig. 9 was operated with these propellants and the performance values obtained are shown in Fig. 10.

Figure 11 is a photograph of the resistojet constructed for use on the Space Station. Figure 12 is a cross-sectional sketch of this resistojet with the major-features identified. This design is a result of a Rocketdyne/Technion effort, on contract to NASA Lewis. The design choices, features, and construction details are to be found in Ref. 15 . Four resistojets of this type are to be constructed and used in performance characterization and life tests. Based on the information obtained from these extensive tests, the resistojet will be redesigned to correct any life and/or performance deficiencies. The redesign also has a goal to reduce the amount of platinum required and to simplify the construction and assembly, where possible.

\section{Concluding Remarks}

The Advanced Development Program explored propulsion options in detail and produced results that have indicated major economies for the Space Station by their use and their ability to utilize waste fluids as propellants. The Space Station baseline propulsion system has been changed to the highthrust oxygen-hydrogen and low-thrust multipropellant resistojet propulsion systems. The advantages to the station by the use of this dual-mode approach will continue to grow if the demands for increased propulsion capability escalate with time. Program efforts will continue as the issues of life determination and failure modes are very important and require a long-term dedicated effort.

\section{Acknowledment}

The author gratefully acknowledges the work done by Robert Tacina and the other members of the Lewis Research Center Advanced Development Plans and Program office for their work in identifying and quantifying the new propulsion requirements and the availability of water and waste fluids for propulsion.

\section{References}

1. Richmond, R.J., and Jones, L.W., "Space Station Advanced Propulsion and Fluid Management Program," 1985 JANNAF Propulsion Meet ing, Vol. 1, Edited by K.L. Strange, CPIA-PUBL-425, Chemical Propulsion Information Agency, Laure1, MD, 1985, pp. 413-421.
2. Jones, R.E., "Space Station Propulsion: The Advanced Development Program at Lewis," AIAA Paper 85-1154, 1985.

3. Donovan, R.M., Sovey, J.S., and Hannum, N.B., "Space Station Propulsion Analys is Study," AIAA Paper 84-1326, June 1984.

4. Klemetson, R.W., Garrison, P.W., and Hannum, N.B., "An Evaluation of Oxygen/Hydrogen Propulsion Systems for the Space Station," AIAA Paper 85-1156, July 1985.

5. Shoji, J.M., et al., "Oxygen/Hydrogen Space Station Propulsion System Concept Definition for IDC," AIAA Paper 86-1561, June 1986.

6. Robinson, P.J. and Rosenthal, S.E., "A Proven 25- Ibf $\mathrm{H}_{2} / \mathrm{O}_{2}$ Thruster for Space Station Auxiliary Propulsion," AIAA Paper 86-1560, June 1986.

7. Senneff, J.M. and Richter, G.P., "A Long-Life 50 lbf $\mathrm{H}_{2} / \mathrm{O}_{2}$ Thruster for Space Station Auxiliary Propulsion," AIAA Paper 86-1404, June 1986.

8. Heckert, B.J., Allums, S.L., and Carrosquillo, E.A., "25 lbf Gaseous 0xygen-Gaseous Hydroqen Thruster for Space Station," Presented at 1986 JANNAF Propulsion Meeting. New Orleans, LA, Aug. 26-28, 1986.

9. Richter, G.P. and Price, H.G., "Proven, LongLife Hydrogen/0xygen Thrust Chambers for Space Station Propulsion," NASA TM-88822, presented at 1986 JANNAF Propulsion Meeting, New Orleans, LA, Aug. 26-28, 1986.

10. McKevitt, F.X., "Design and Development Approach for the Augmented Catalytic Thruster (ACT)," AIAA Paper 81-1255, June 1983.

11. Mirtich, M.J., "Resistojet Propulsion for Larqe Spacecraft Systems," AIAA Paper 82-1948, Nov. 1982.

12. Whalen, M.V., Grisnik, S.P. and Sovey J.S., "Compatibility Experiments of Facilities, Materials and Propellants for Electrothermal Thrusters," 1985 JANNAF Propulsion Meeting, Vol. 1, Edited by K.L. Strange, CPIA-PUBL-425, Chemical Propulsion Information Agency, Laurei, MD, 1985, pp. 475-484.

13. Morren, W.E., Whalen, M.V. and Sovey, J.S., "Performance for Space Station Auxiliary Propulsion," AIAA Paper 86-1435, June 1986.

14. Personal Communication: Margaret $V$. Whalen., NASA Lewis Research Center, Cleveland, $\mathrm{OH}$, Sept. 1986.

15. Pugmire, T.K., Cann, G.L., Heckert, B., and Sovey, J.S., "A 10,000 Hour Life Multipropellant Engine for Space Station Application," AIAA Paper 86-1403, June 1986. 
TABLE 1. - TOTAL-IMPULSE REQUIRED FOR REBOOST/ALTITUDE MAINTENANCE

[Nominal atmosphere assumed.]

\begin{tabular}{|c|c|c|c|}
\hline Year & \multicolumn{2}{|c|}{$\begin{array}{c}\text { Variable altitude } \\
\text { average, } \\
0.3 \text { micro-g }\end{array}$} & $\begin{array}{c}\text { Nominal 250 nmi } \\
\text { altitude }\end{array}$ \\
\cline { 2 - 5 } & $\begin{array}{c}\text { Altitude, } \\
\text { nmi }\end{array}$ & $\begin{array}{c}\text { Impulse, } \\
\text { lbf/sec }\end{array}$ & $\begin{array}{c}\text { Impulse, } \\
\text { lbf/sec }\end{array}$ \\
\hline 1995 & 189 & 3840854 & 657840 \\
1996 & 184 & 4500470 & 358910 \\
1997 & 180 & 5054046 & 313331 \\
1998 & 180 & 4855411 & 278491 \\
1999 & 180 & 5356076 & 306930 \\
2000 & 192 & 4753118 & 523467 \\
2001 & 202 & 5274946 & 1027970 \\
2002 & 213 & 5967411 & 1905387 \\
2003 & 221 & 6480000 & 2646000 \\
2004 & 210 & 7478224 & 2162223 \\
2005 & 205 & 7621082 & 1718600 \\
\hline Total & & 61181635 & 11899149 \\
\hline
\end{tabular}

TABLE 2. - WATER AVIALABLE FOR PROPULSION $1 \mathrm{bm} / \mathrm{yr}$

\begin{tabular}{|c|c|c|c|c|c|c|c|c|c|c|c|}
\hline Options & 1995 & 1996 & 1997 & 1998 & 1999 & 2000 & 2001 & 2002 & 2003 & 2004 & Total \\
\hline $\begin{array}{l}45 \text { Day visits } \\
\text { Bosch ECLSS }\end{array}$ & 18140 & 18630 & 18480 & 18970 & 18815 & 19305 & $19 \quad 155$ & 19645 & 19490 & 19980 & 190610 \\
\hline $\begin{array}{l}90 \text { Day visits } \\
\text { Bosch ECLSS }\end{array}$ & 9735 & 10185 & 10030 & 10520 & 10370 & 10860 & 10710 & 11195 & 11045 & 11530 & $106 \quad 180$ \\
\hline $\begin{array}{l}45 \text { Day visits } \\
\text { Sabatier ECLSS }\end{array}$ & 15585 & 1542.5 & 15280 & 15130 & 14980 & 14830 & 14675 & 14525 & 14370 & 14220 & 149020 \\
\hline $\begin{array}{l}90 \text { Day visits } \\
\text { Sabatier ECLSS }\end{array}$ & 7175 & 6985 & 6830 & 6680 & 6530 & 6380 & 6230 & 6075 & 5925 & 5770 & 64580 \\
\hline
\end{tabular}


TABLE 3. - SUMMARY OF FLUIDS AVAILABLE FOR PROPULSION FROM ECLSS $1 \mathrm{bm} / \mathrm{yr}$

\begin{tabular}{|c|c|c|c|c|c|c|c|c|c|c|}
\hline \multirow[t]{2}{*}{ Fluid } & \multicolumn{10}{|c|}{ Year } \\
\hline & 1995 & 1996 & 1997 & 1998 & 1999 & 2000 & 2001 & 2002 & 2003 & 2004 \\
\hline $\begin{array}{l}\text { (Bosch) } \\
\text { Hydrogen }\end{array}$ & 41.4 & 51.8 & 51.8 & 62.1 & 62.1 & 72.5 & 72.5 & 82.8 & 82.8 & 93.2 \\
\hline (Sabatier) & & & & & & & & & & \\
\hline $\begin{array}{c}\text { C02 } \\
\text { Methane }\end{array}$ & $\begin{array}{l}564 \\
371\end{array}$ & $\begin{array}{l}705 \\
464\end{array}$ & $\begin{array}{l}705 \\
464\end{array}$ & $\begin{array}{l}846 \\
557\end{array}$ & $\begin{array}{l}846 \\
557\end{array}$ & $\begin{array}{l}987 \\
649\end{array}$ & $\begin{array}{l}987 \\
649\end{array}$ & $\begin{array}{r}1128 \\
742\end{array}$ & $\begin{array}{r}1128 \\
742\end{array}$ & $\begin{array}{r}1269 \\
835\end{array}$ \\
\hline Total $\mathrm{CO}_{2} / \mathrm{CH}_{4}$ & 935 & 1169 & 1169 & 1403 & 1403 & 1636 & 1636 & 1870 & 1870 & 2104 \\
\hline
\end{tabular}

TABLE 4. - ESTIMATE OF FLUIOS AVAILABLE FOR PROPULSION FROM MTL $1 \mathrm{bm} / \mathrm{yr}$

\begin{tabular}{|l|c|c|c|c|c|c|c|c|c|c|}
\hline \multirow{2}{*}{ Fluid } & \multicolumn{10}{|c|}{ Year } \\
\cline { 2 - 10 } & 1995 & 1996 & 1997 & 1998 & 1999 & 2000 & 2001 & 2002 & 2003 & 2004 \\
\hline Argon & 56 & 63 & 70 & 77 & 84 & 90 & 97 & 104 & 111 & 118 \\
C02 & 21.3 & 24 & 27 & 29 & 32 & 34 & 37 & 40 & 42 & 45 \\
Helium & 4 & 4.5 & 5 & 5.5 & 6 & 6.5 & 7 & 7.5 & 8 & 8.5 \\
Nitrogen & 314 & 353 & 391 & 430 & 468 & 507 & 545 & 584 & 622 & 661 \\
Hydrogen & .3 & .3 &. .4 & .4 & .4 & .5 & .5 & .5 & .6 & 0.6 \\
Totals & 395.6 & 444.8 & 493.4 & 541.9 & 590.4 & 638 & 686.5 & 736 & 783.6 & 833.1 \\
\hline
\end{tabular}


TABLE 5. - TOTAL OF FLUIDS AVAILABLE FROM ALL SOURCES WITH SABATIER ECLSS $1 \mathrm{bm} / \mathrm{yr}$

\begin{tabular}{|c|c|c|c|c|c|c|c|c|c|c|}
\hline \multirow{2}{*}{ Fluid } & \multicolumn{10}{|c|}{ Year } \\
\cline { 2 - 10 } & 1995 & 1996 & 1997 & 1998 & 1999 & 2000 & 2001 & 2002 & 2003 & 2004 \\
\hline Argon & 403.2 & 415.5 & 427.8 & 440.2 & 452.2 & 463.6 & 475.9 & 488.2 & 500.4 & 512.7 \\
C0. & 149.9 & 167.6 & 185.1 & 202.6 & 220.6 & 237.6 & 255.6 & 273.6 & 290.6 & 308.6 \\
Helium & 78.8 & 87.4 & 96 & 104.6 & 113.2 & 121.9 & 130.5 & 139.1 & 147.8 & 156.3 \\
Hydrogen & 35.7 & 40 & 44.5 & 48.8 & 53.1 & 57.6 & 61.9 & 66.2 & 70.7 & 75 \\
CO2/Methane & 935 & 1169 & 1169 & 1403 & 1403 & 1636 & 1636 & 1870 & 1870 & 2104 \\
Nitrogen & 458 & 514.7 & 570.3 & 627 & 682.7 & 739.3 & 795 & 851.7 & 907.3 & 964 \\
Krypton & 19.8 & 19.8 & 19.8 & 19.8 & 19.8 & 19.8 & 19.8 & 19.8 & 19.8 & 19.8 \\
Totals & 2080.4 & 2414 & 2512.5 & 2846 & 2944.6 & 3275.8 & 3374.7 & 3708.6 & 3806.6 & 4140.4 \\
\hline
\end{tabular}

TABLE 6. - H/O THRUSTER INITIAL DESIGN GOALS

\begin{tabular}{|l|r|r|r|}
\hline & Rocketdyne & Aerojet & \multicolumn{1}{|c|}{ Bell } \\
\hline Thrust, lbf & 25 & 25 & 50 \\
Specific impulse, sec & 415 & 440 & 410 \\
Nozzle area ratio & 30 & 100 & 40 \\
Chamber pressure, psia & 100 & 75 & 75 \\
Throat diameter, in. & 0.42 & 0.5 & 0.69 \\
Exit diameter, in. & 2.3 & 5.0 & 4.39 \\
Type & Regen cooled & Regen cooled & Film cooled \\
\hline
\end{tabular}


TABLE 7. $-\mathrm{O}_{2} / \mathrm{H}_{2}$ THRUSTER TEST SUMMARY

\begin{tabular}{|c|c|c|c|c|c|c|}
\hline \multirow{2}{*}{$\begin{array}{c}\text { Mixture } \\
\text { ratio, } \\
\text { F }\end{array}$} & \multicolumn{2}{|c|}{ Aerojet } & \multicolumn{2}{|c|}{ Bell } & \multicolumn{2}{|c|}{ Rocketdyne } \\
\hline & $\begin{array}{c}\text { Total } \\
\text { duration, } \\
\text { sec }\end{array}$ & $\begin{array}{l}\text { Total } \\
\text { impulse, } \\
\text { lbf/sec }\end{array}$ & $\begin{array}{c}\text { Total } \\
\text { duration, } \\
\text { sec }\end{array}$ & $\begin{array}{c}\text { Total } \\
\text { impulse, } \\
1 \mathrm{bf} / \mathrm{sec}\end{array}$ & $\begin{array}{c}\text { Total } \\
\text { duration, } \\
\text { sec }\end{array}$ & $\begin{array}{l}\text { Total } \\
\text { impulse, } \\
\text { lbf/sec }\end{array}$ \\
\hline $\begin{array}{l}2 \\
3 \\
4 \\
5 \\
6 \\
7 \\
8\end{array}$ & $\begin{array}{r}60 \\
180 \\
4 \quad 039 \\
224 \\
221 \\
17 \quad 560 \\
118 \\
\end{array}$ & $\begin{array}{rr}1302 \\
5 & 107 \\
89 & 526 \\
5 & 576 \\
4 & 728 \\
428 & 997 \\
3 & 221 \\
\end{array}$ & $\begin{array}{rr}- & 275 \\
1 \quad 619 \\
124 \\
83 \\
\\
\\
3 \quad 116 \\
\end{array}$ & $\begin{array}{rr}13 & 470 \\
79 & 637 \\
6 & 123 \\
4 & 367 \\
3 & 449 \\
225 & 607 \\
\end{array}$ & $\begin{array}{rr}32 & 148 \\
12 & 697 \\
408 \\
478 \\
440 \\
40 \quad 237 \\
\end{array}$ & $\begin{array}{r}803 \\
317400 \\
10200 \\
11950 \\
11000 \\
1 \quad 005925 \\
\end{array}$ \\
\hline & 22402 & 538457 & 5282 & 332653 & 85968 & 2149200 \\
\hline
\end{tabular}

TABLE 8. - SUMMARY OF GRAIN STABILIZED PLATINUM EXPERIMENTS

\begin{tabular}{|c|c|c|c|c|}
\hline Propellant & $\begin{array}{c}\text { Coiled } \\
\text { heater } \\
\text { temperature, } \\
{ }_{C}\end{array}$ & $\begin{array}{c}\text { Heater } \\
\text { initial } \\
\text { mass, } \\
g\end{array}$ & $\begin{array}{c}\text { Coiled } \\
\text { heater } \\
\text { mass } \\
\text { loss } \\
g^{a}\end{array}$ & $\begin{array}{c}\text { Extrapol ated } \\
\text { iffe, } \\
\text { hr }\end{array}$ \\
\hline \multicolumn{5}{|c|}{ Platinum - Yttria } \\
\hline $\mathrm{CO}_{2}$ & 1400 & 9.0194 & 0.0030 & 300000 \\
\hline $\mathrm{CH}_{4}$ & 500 & 12.6384 & .0008 & 1500000 \\
\hline $\mathrm{H}_{2}$ & 1400 & 12.6589 & .0062 & 200000 \\
\hline $\mathrm{NH}_{3}$ & 1400 & 12.5982 & .0055 & 200000 \\
\hline $\mathrm{H}_{2} \mathrm{O}$ & 1400 & 13.0695 & .0116 & 113000 \\
\hline \multicolumn{5}{|c|}{ Platinum - Zirconia } \\
\hline $\mathrm{CO}_{2}$ & 1400 & 13.1955 & 0.0016 & 800000 \\
\hline $\mathrm{CH}_{4}$ & 500 & 11.6969 & $.0000^{C}$ & 1000000 \\
\hline $\mathrm{H}_{2}$ & 1400 & 13.2093 & .0031 & 400000 \\
\hline $\mathrm{NH}_{3}$ & 1400 & 13.0632 & .0066 & 200000 \\
\hline $\mathrm{H}_{2} \mathrm{O}$ & 1400 & 11.5133 & .0245 & 45000 \\
\hline
\end{tabular}

after $1000 \mathrm{hr}$ operation.

bTime to 10 percent mass 1oss.

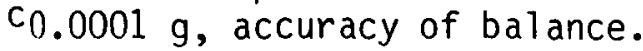


TABLE 9. - SPACE STATION MULTIPROPELLANT RESISTOJET PERFORMANCE GOALS

\begin{tabular}{|c|c|c|c|c|c|}
\hline Propellant & $\mathrm{CO}_{2}$ & $\begin{array}{c}\mathrm{H}_{2} \mathrm{O} \\
\text { (Steam) }\end{array}$ & $\mathrm{CO}_{2} / \mathrm{CH}_{4}$ & $\begin{array}{c}\mathrm{N}_{2} \mathrm{H}_{4} \\
\text { decomp. } \\
\text { prod. }\end{array}$ & $\mathrm{H}_{2}$ \\
\hline $\begin{array}{l}\text { Thrust, mlbf } \\
\text { Specific impulse, s } \\
\text { Power, w } \\
\text { Design life, hr } \\
\text { Total impulse per } \\
\text { thruster, lbf-s } \\
\text { Yearly resupply impulse } \\
\text { for reboost, ref. } \\
\text { ss config. ibf-s } \\
\text { Mass throughput at } \\
\text { design life, lbm }\end{array}$ & $\begin{array}{l}110 \\
130 \\
500 \\
10000 \\
4 \times 10^{6} \\
2 \times 10^{6}\end{array}$ & $\begin{array}{l}90 \\
200 \\
500 \\
10000 \\
3 \times 10^{6} \\
2 \times 10^{6}\end{array}$ & $\begin{array}{c}85 \\
160 \\
500 \\
10000 \\
3 \times 10^{6} \\
2 \times 10^{6}\end{array}$ & $\begin{array}{l}90 \\
250 \\
500 \\
10000 \\
3 \times 10^{6} \\
2 \times 10^{6} \\
13000\end{array}$ & $\begin{array}{c}30 \\
500 \\
500 \\
10000 \\
1 \times 10^{6} \\
2 \times 10^{6}\end{array}$ \\
\hline
\end{tabular}


ORIGINAL PIGE IS

a. FOOR QUALTYY

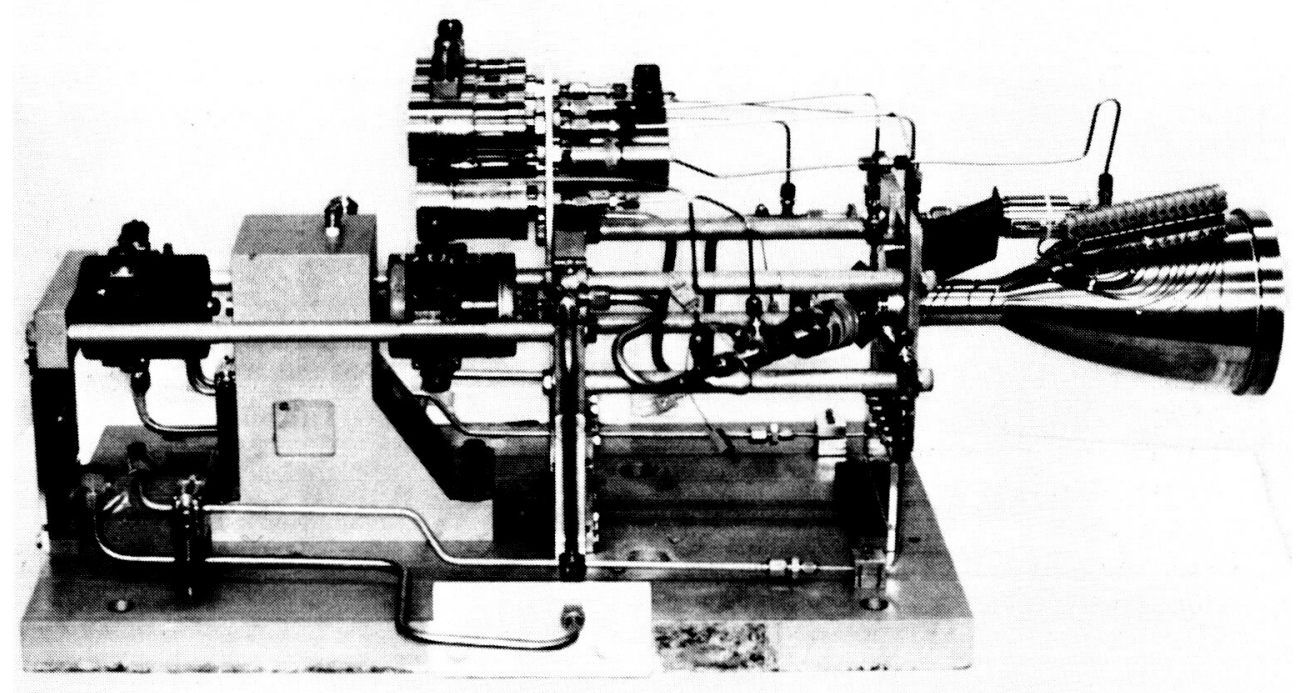

C-86-1827

Figure 1. - AEROJET 25- Ibf ROCKET ENGINE ON THRUST STAND. 


\section{ORIGINAL PACE is
OF POOR QuAMTY}

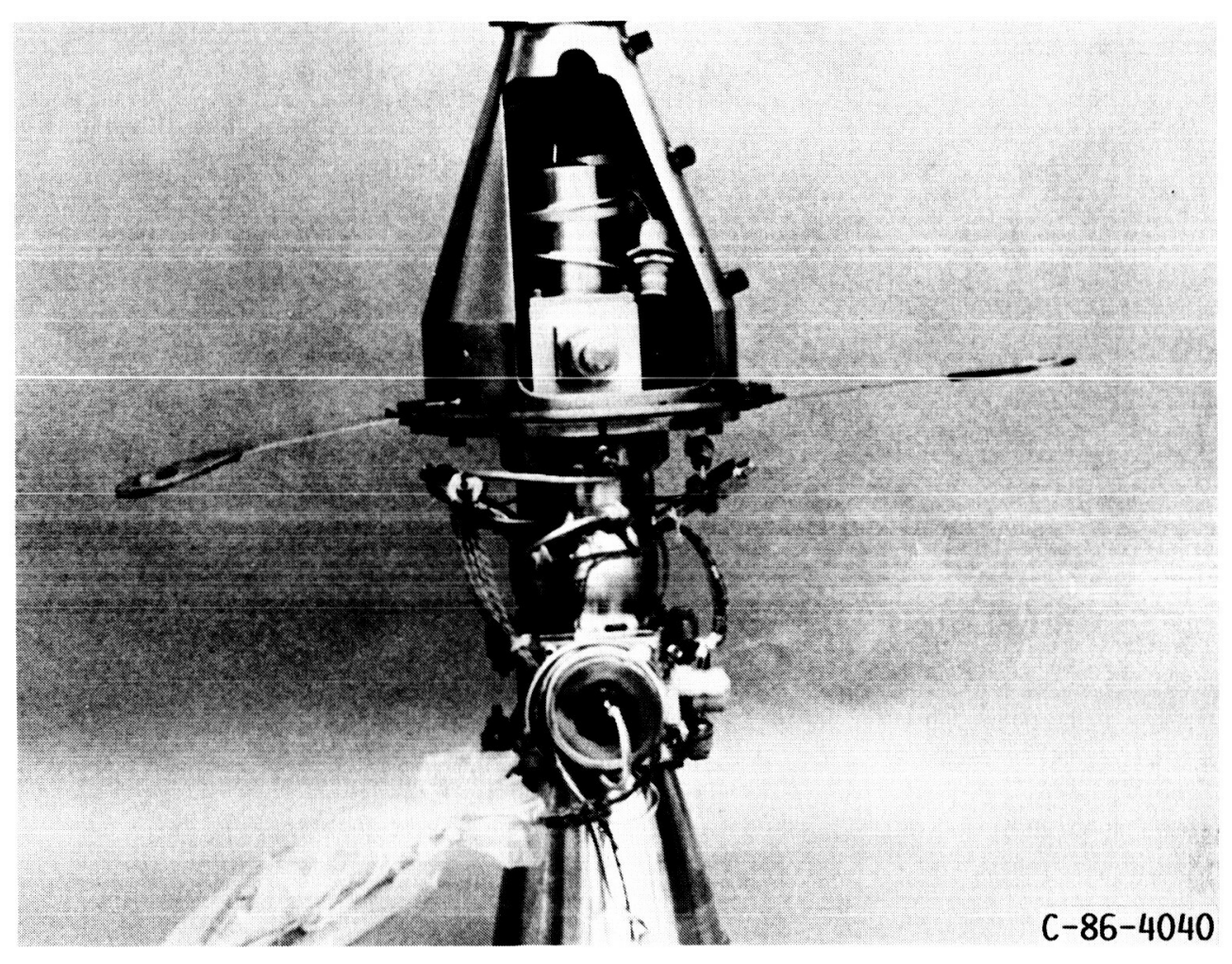

Figure 2. - BELL AEROSPACE 50- Ibf thrust hydROgEN/OXYGEN ROCKET. 


\section{ORIGINAL PAGE IS \\ OF POOR QUALTY}

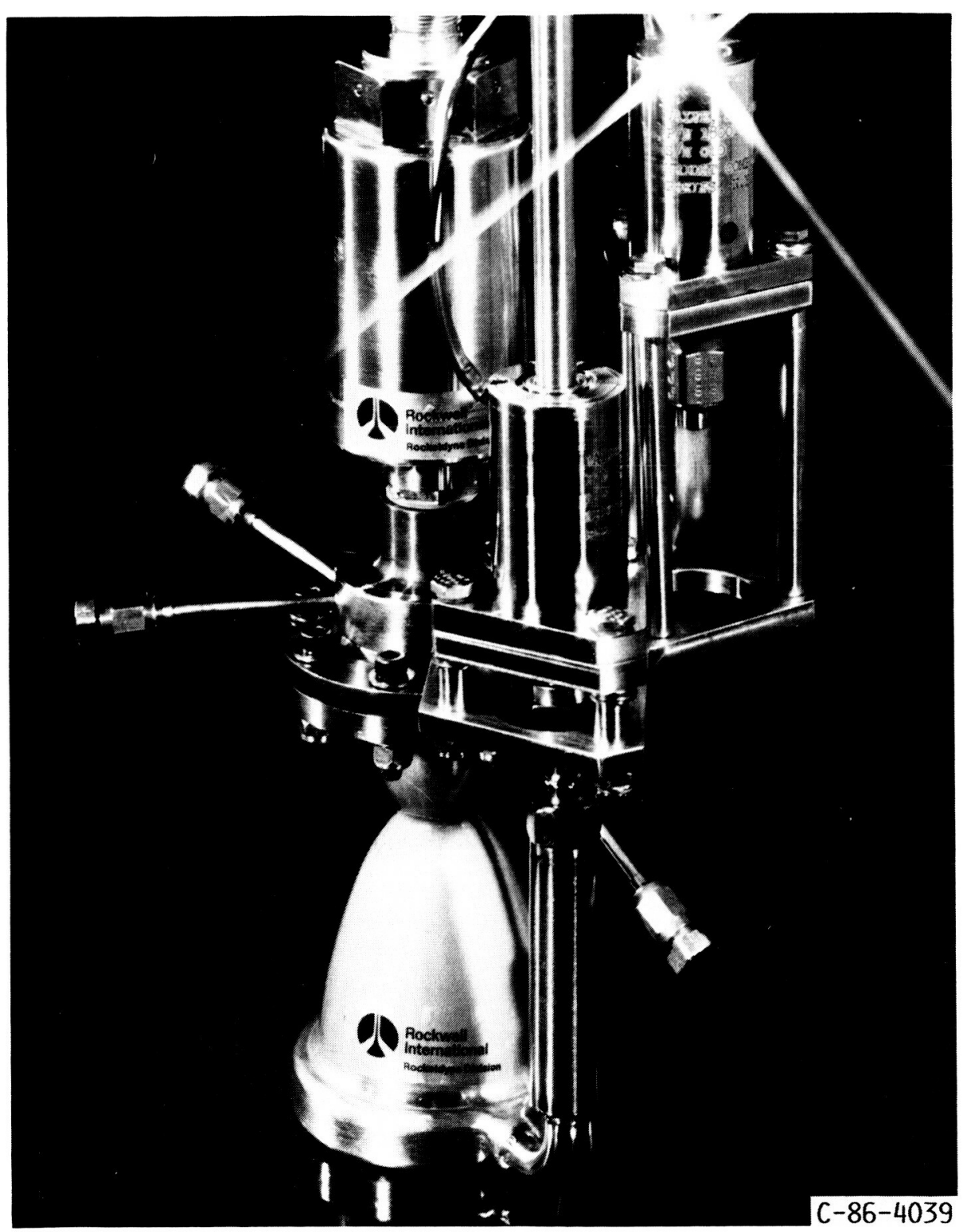

FIGURE 3. - ROCKETDYNE 25-Ibf THRUST HYDROGEN/OXYGEN ROCKET. 


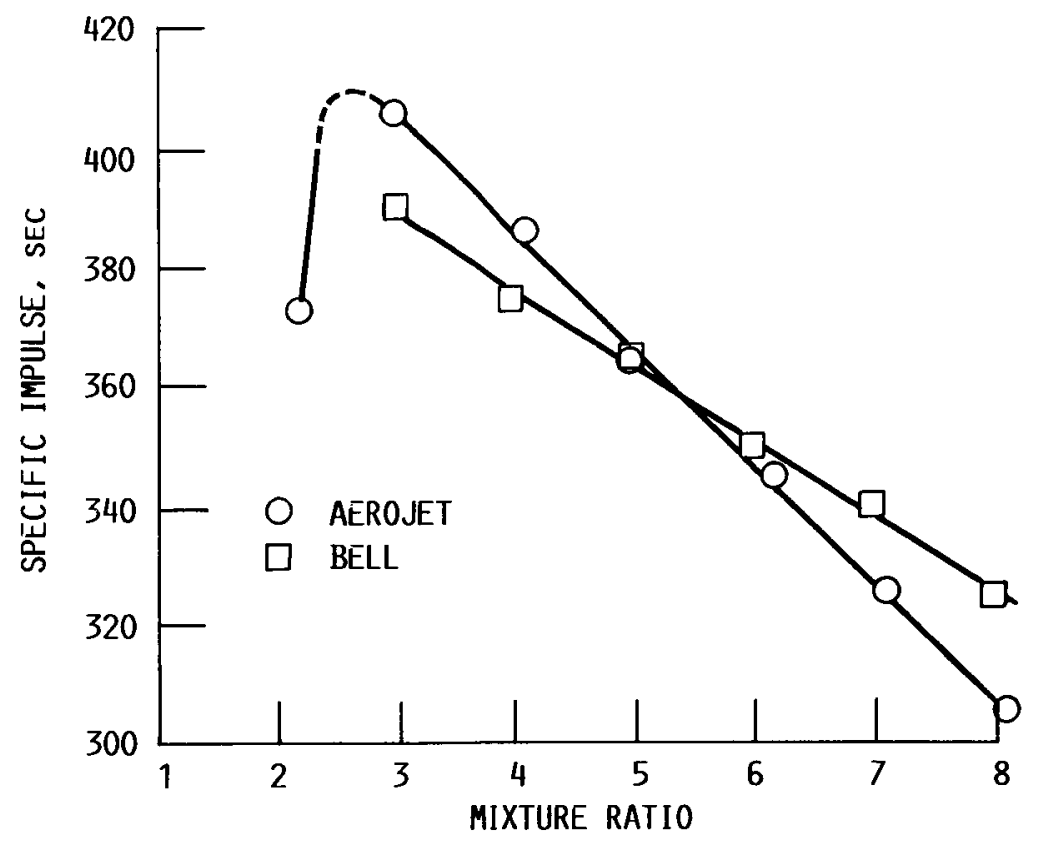

Figure 4.- Performance of H/0 thrusters oVer A RANGE OF MIXTURE RATIOS. 


\section{orieinal page is of POOR QUALTY}

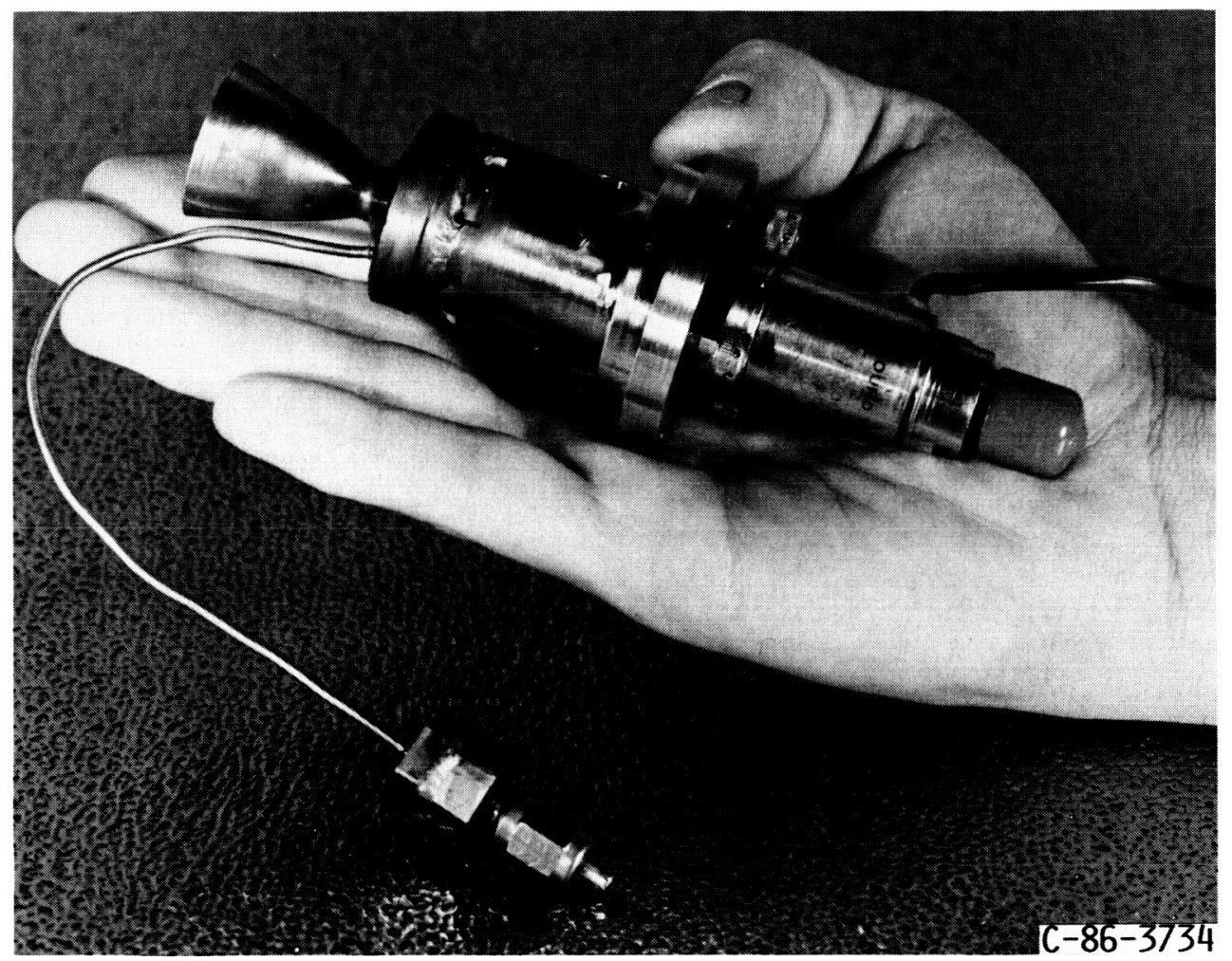

Figure 5. - SMALL hYDRAZINE THRUSTER FOR LIFE TESTS. 


\section{ORIGINAL PACE IS \\ OF POOR QUALTY}

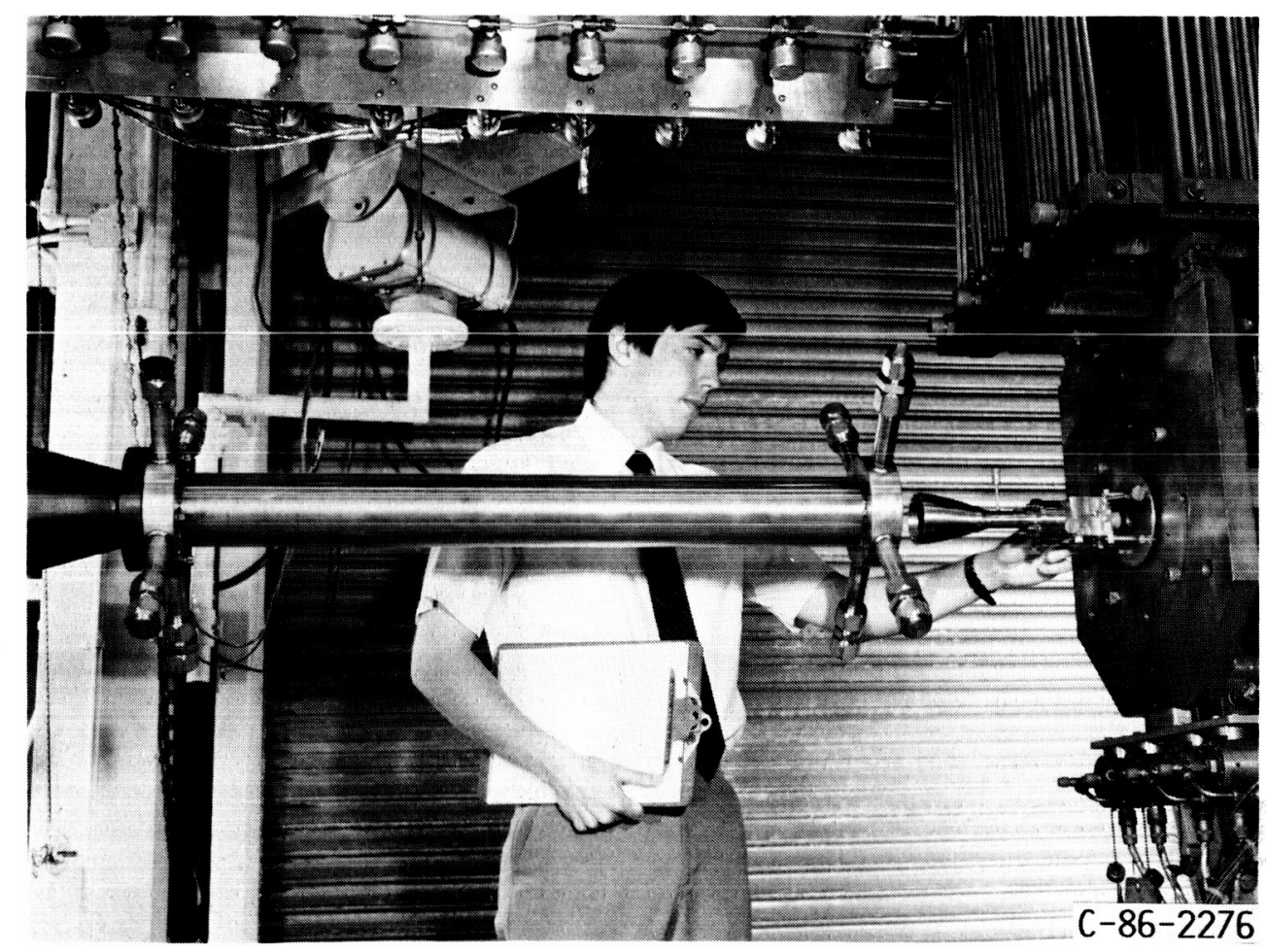

Figure 6. - HYDRAZINE THRUSTER AND DifFusER AT THE ROCKET ENGINE TEST FACILITY. 
ORIGINAL PAGE IS

OF POOR QUALTY

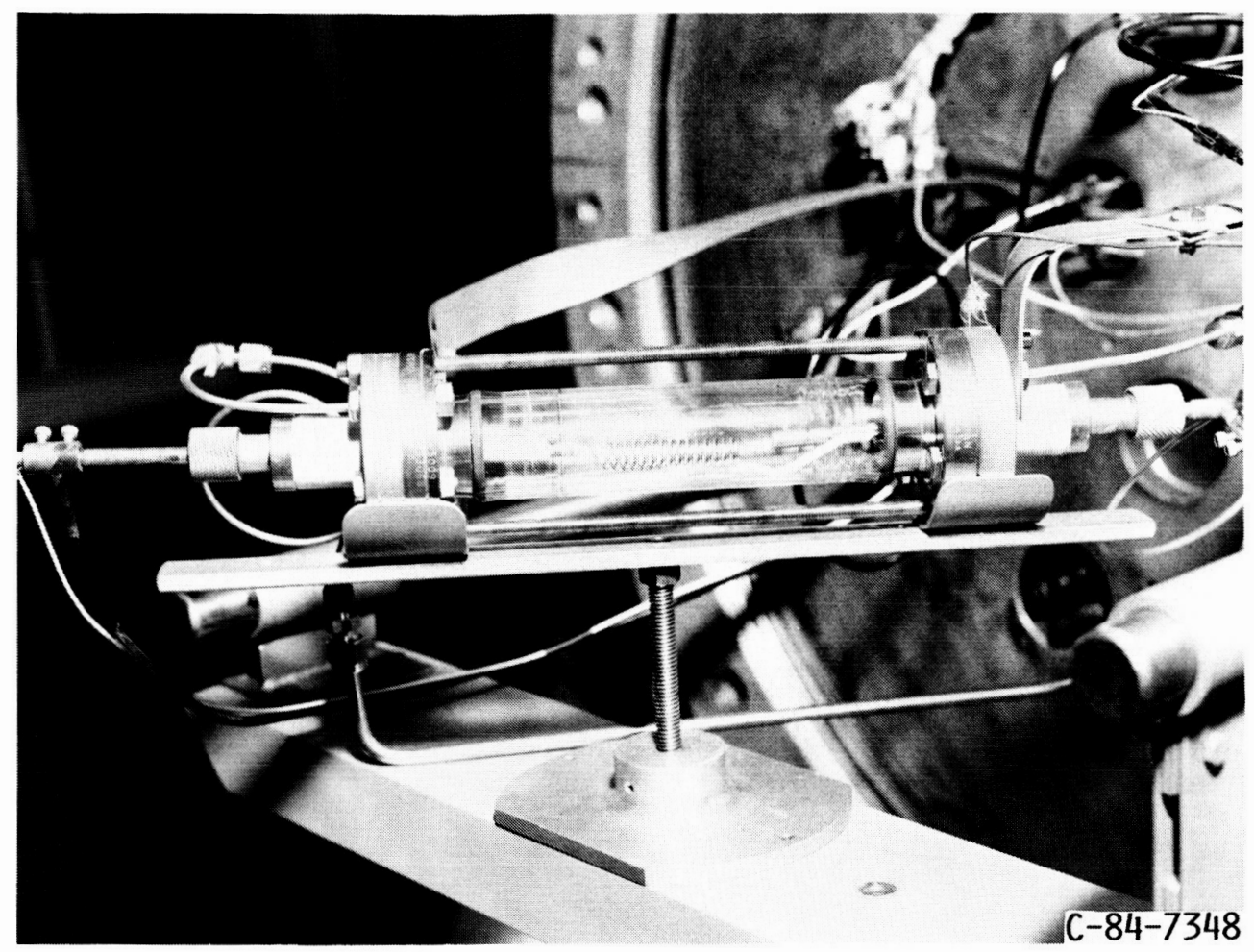

Figure 7. - Test apparatus used to eVAluate PROPELLANT-MATERIAL COMPATABILITY FOR LONG-LIFE RESISTOJETS. 


\section{ORIGINAL PAGE IS \\ OF POOR QUALTY}

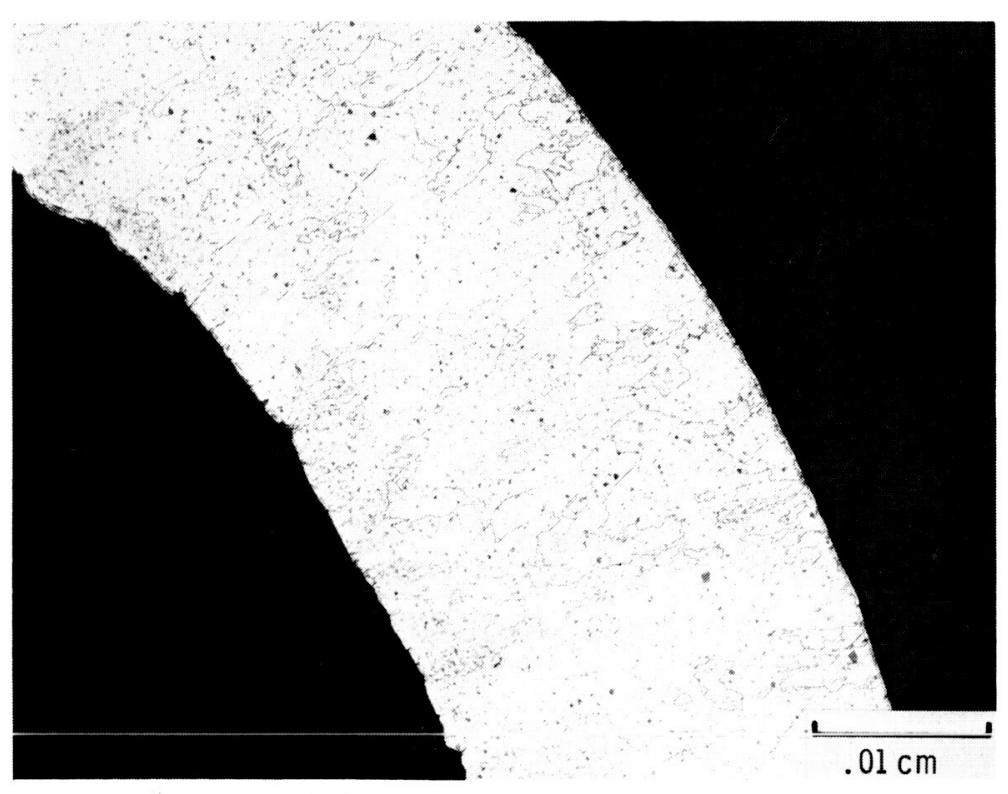

BEFORE

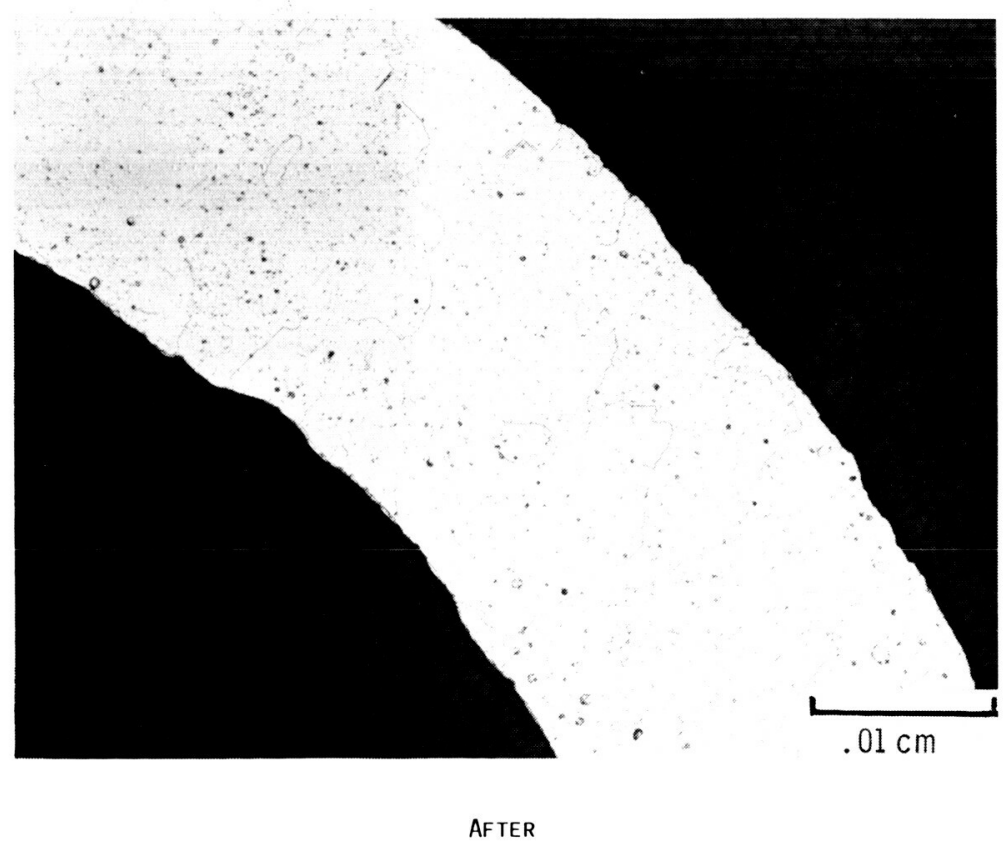

FIgURE 8. - CROSS SECTION OF PT/ $\mathrm{Y}_{2} \mathrm{O}_{3}$ TUBE BEFORE AND AFTER TESTING FOR 2000 HR AT $1300^{\circ} \mathrm{C}$ IN CO 2. 


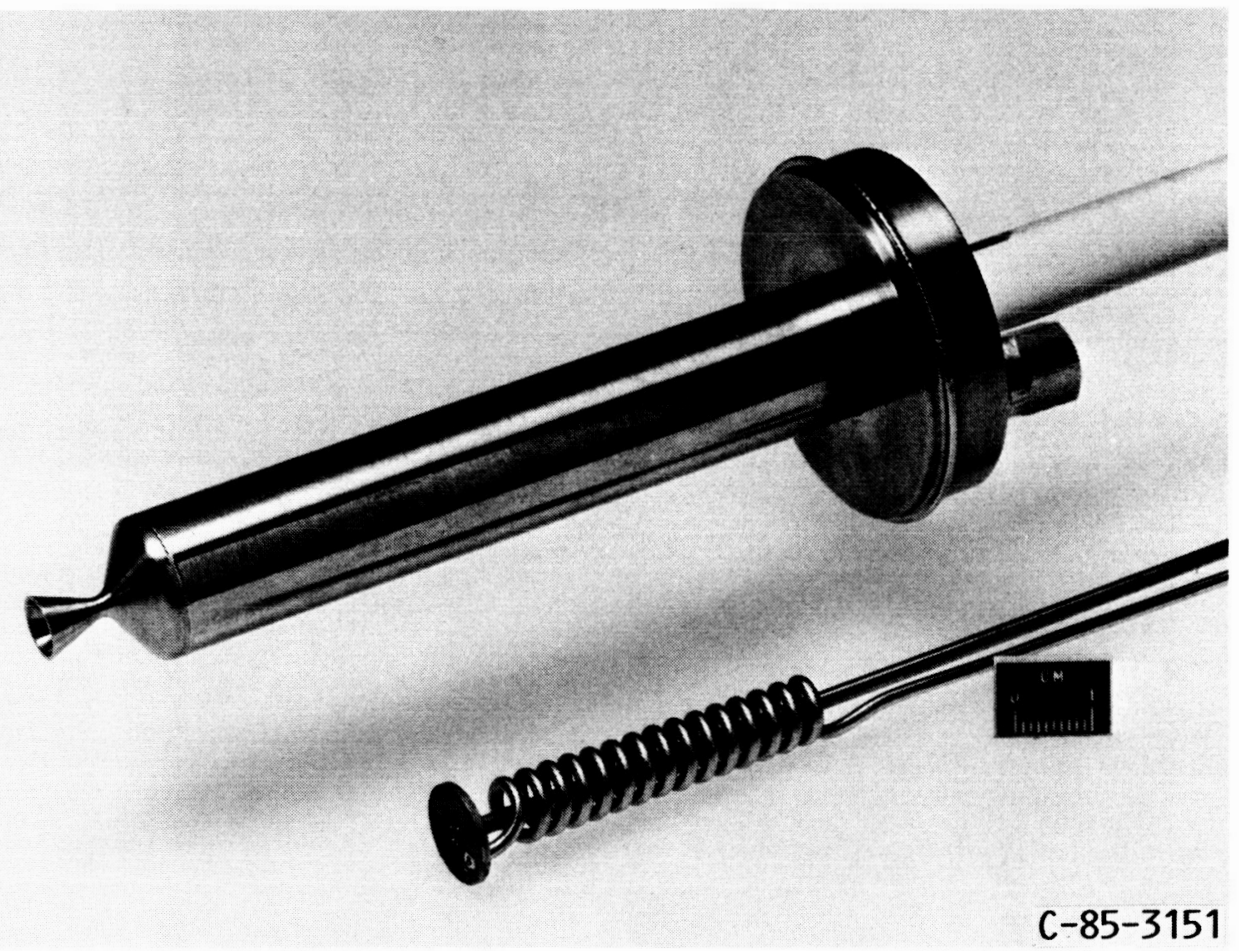

Figure 9. - LABORATORY MODEL OF RESISTOJET AND COILED TUBE HEATER. 


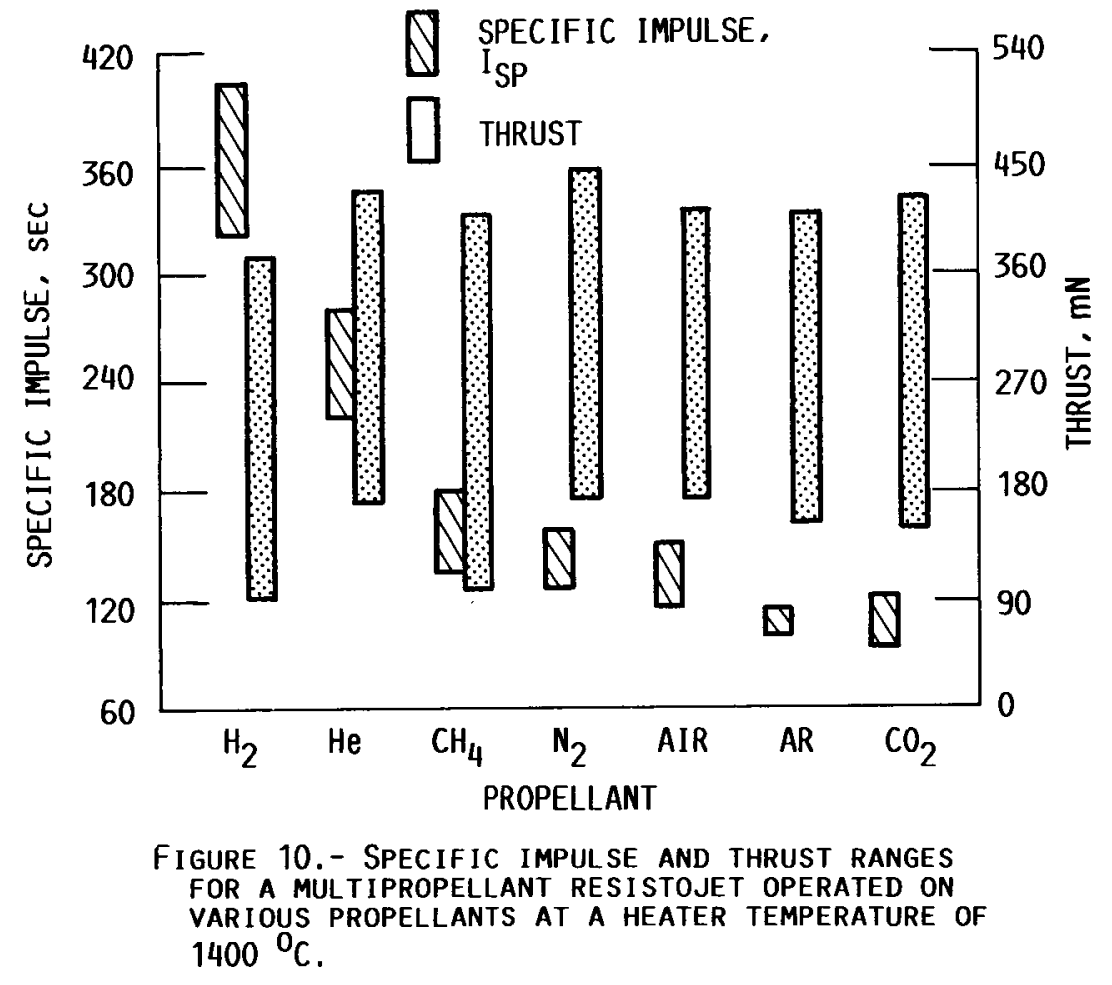




\section{ORIGINAL PAOE IS \\ Or POOR QUALTTY}

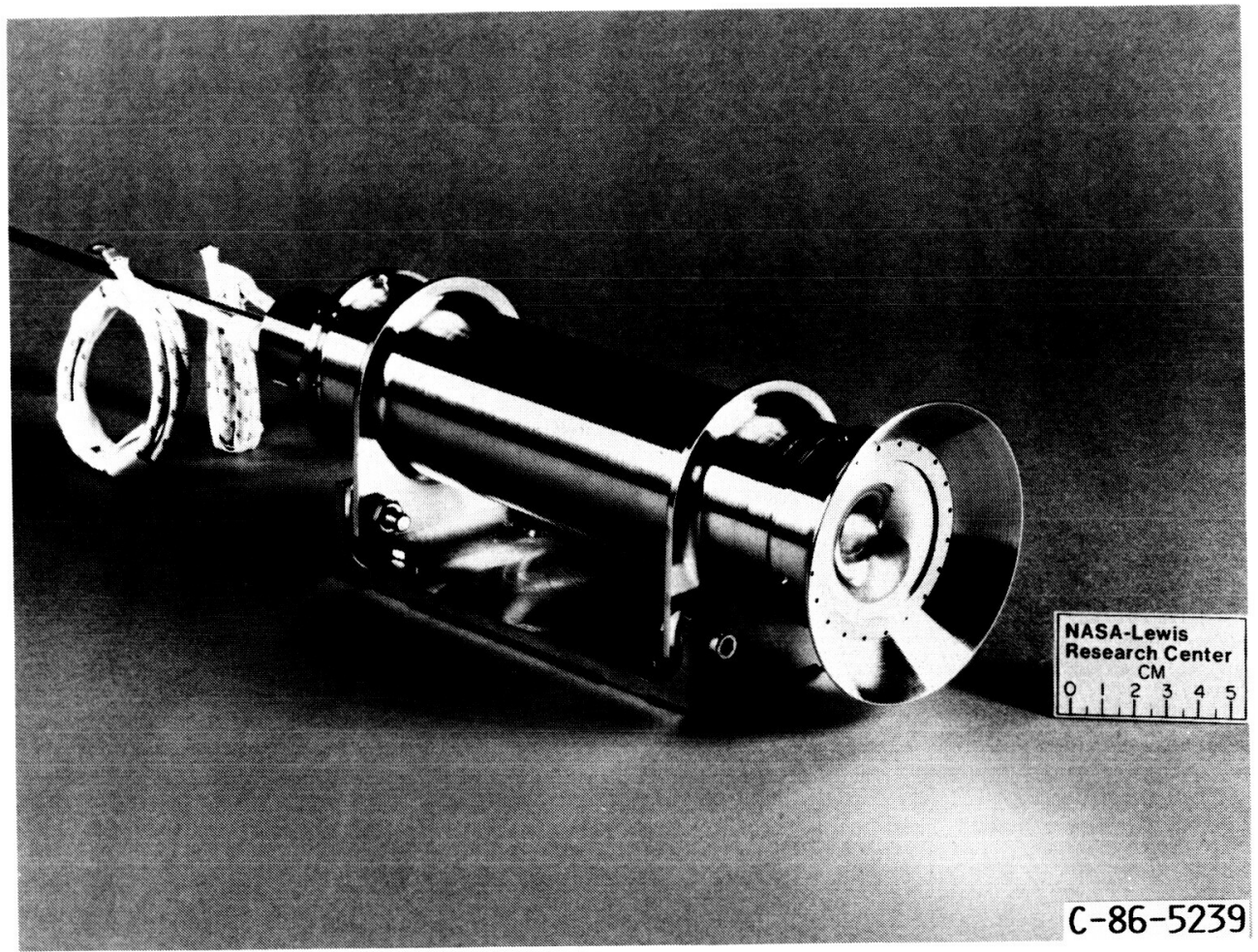

Figure 11. - ENGINEERING MODEL OF RESISTOJET. 


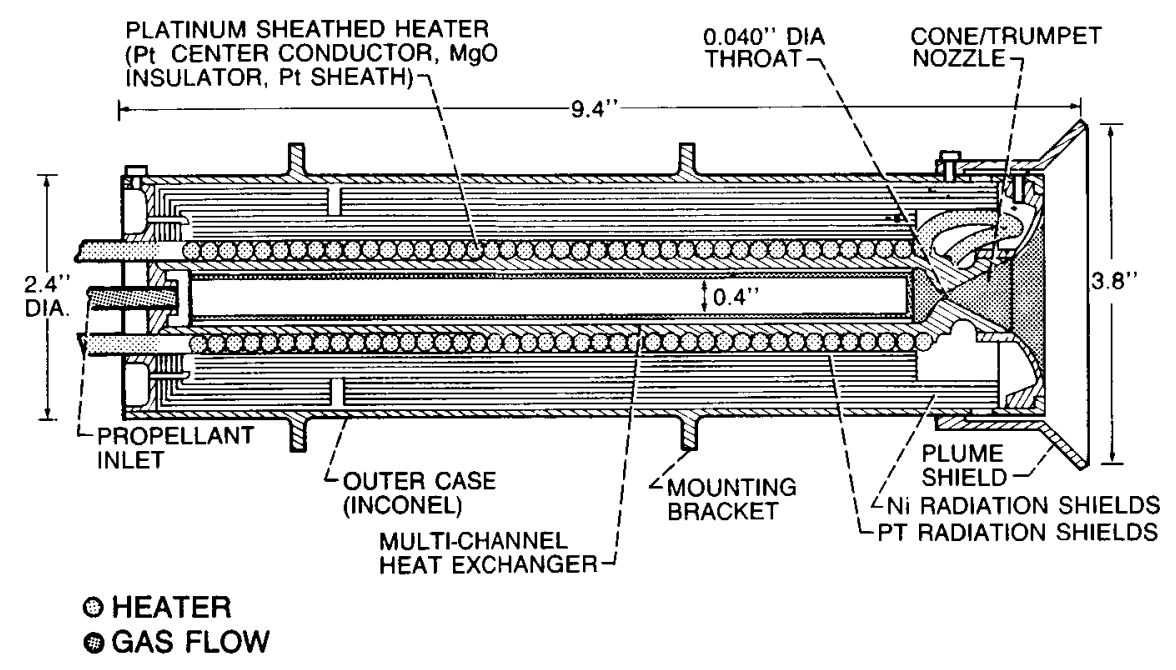

Figure 12. - CROSS-SECTIONAL SKETCH OF ENGINEERING MODEL OF RESISTOJET. 


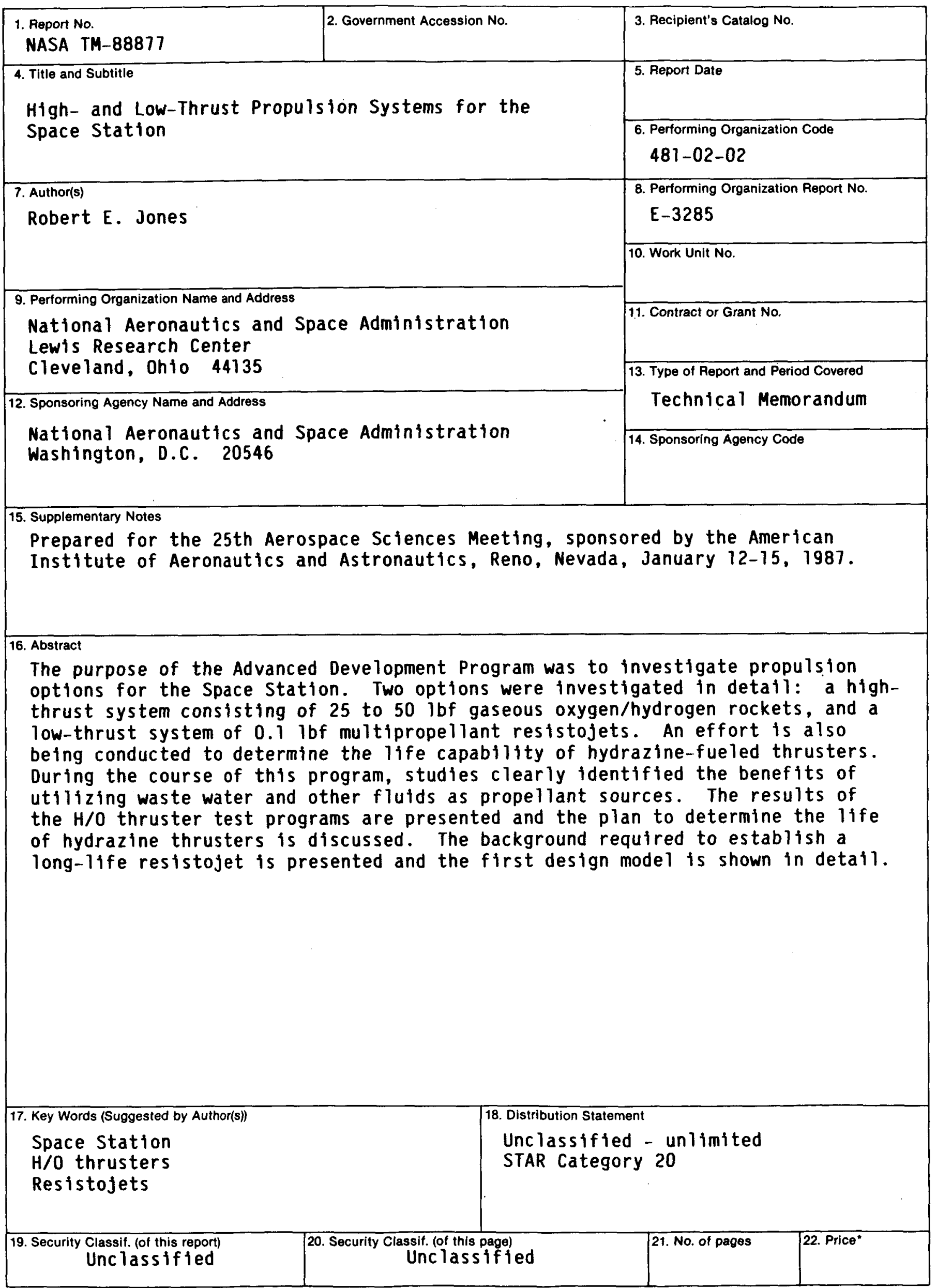

"For sale by the National Technical Information Service, Springfield, Virginia 22161 